\title{
Emotions of Medical Personnel versus the Status and Power at Work in Hospital Wards
}

\author{
Beata Pawłowska \\ University of Lodz, Poland
}

DOI: https://doi.org/10.18778/1733-8069.17.4.04

\section{Keywords:}

emotions, work, pride, status, power, Theodore Kemper, medical personnel, hospital

\begin{abstract}
The hospital is characterized by one of the most formalized structures with a strict division of tasks and responsibilities. An essential element of any formal organization is the system of authorities and power. There is a hierarchy and a system of power between hospital departments and within each of them. This hierarchy structure overlaps with the level of power and status felt and perceived by each employee, which implies the emergence of specific emotions. They influence interactions, shaping their course. When describing emotions in the context of power and status, I will refer to Theodore Kemper's concept that interactions and changes in the relative power and status (prestige) of individuals have an impact on arousing both negative and positive emotions.

The aim of this article is to show how an individually-determined level of power and status can shape relations between employees, their methods of communication, and emotions in the workplace. The paper answers the question of whether and how having and/or feeling a certain status and level of power implies the emergence of certain emotions. It is important to reveal those activities and interactions which, as a result of a specific position in the hospital structure, shape and modify the emotions of medical personnel.

All the considerations are based on ethnographic qualitative research conducted in three hospital departments, differing in terms of the nature of work in the department and the type of patients treated in each of them. The article describes three of the distinguished categories, i.e. "disrespect game," "holding emotions," and pride. In the course of the analyses, it was found that hierarchy and a specific level of power implies the appearance of emotions of pride, satisfaction, and contentment, as well as it leads to an increase in the level of trust between members of medical personnel. Pride results from belonging to a specific profession and a specific group of employees, and it appears as the consequence of a well-conducted procedure or performance of a difficult activity that took time to master. Pride also emerges as a result of the prestige of the profession or workplace (hospital, ward).
\end{abstract}


Beata Pawłowska, an Associate Professor in the field of sociology. A sociology and psychology graduate (specializing in Human Resources Management [HRM]). She works at the Department of Sociology of Organization and Management, Institute of Sociology, Faculty of Economics and Sociology, University of Lodz. A researcher of organizational culture, currently focused on emotional behavior(s) within professional contexts. She is a member of many research teams and a post-graduate Lecturer in coaching, HRM, and public relations. Head of post-graduate studies 'Effective Public Sector Manager'. She is particularly interested in issues regarding emotions in the work environment, including educational environment. She has authored several books, e.g. Network motions are an essential part of the human experience and are an integral part of all interactions and activities, including those in the work environment. They determine the quality of interpersonal relations and are important for many aspects of the activity and level of organizational life (Brief and Weiss 2002). Performing specific duties, working in a specific profession implies the triggering and / or suppression (hiding) of certain emotions. Although it is not the subject of this article, ${ }^{1}$ the requirements of a job (profession) often define the emotions expected to be expressed by employees regardless of the level of their feeling by the individual (Hochschild 1983; 2009; Rafaeli and Sutton 1987). The aim of the article is to show how an individually determined

\footnotetext{
${ }^{1}$ This article is based on the 2020 book by Dominika Byczkowska-Owczarek, Anna Kubczak, and Beata Pawłowska, titled Za drzwiami oddziału. Badania etnograficzne w szpitalu [Behind the Ward Door: Ethnographic Research in a Hospital] (University of Lodz Press, https://wydawnictwo.uni.lodz.pl/wp-content/ uploads/2020/11/Byczkowska-Owczarek-i-in._Za-drzwiami-. pdf [dostęp 24.11.2021]). The authors have not reported a potential conflict of interest. The research was conducted jointly and separate areas of analysis were distinguished in line with the individual interests of each of the researchers.
}

marketing. Kulturowe i osobowościowe wyznaczniki uczestnictwa w Amway [Network Marketing: Cultural and Personality Determinants of Participation in Amway] (2011, University of Lodz Press, ISBN: 978-83-7525-600-0) and Emocje społeczne w pracy nauczyciela i przedstawiciela handlowego [Social Emotions in the Work of Teachers and Salespeople] (2013, University of Lodz Press, ISBN: 978-83-7525-312-2).

\section{Contact details:}

Department of Sociology of Organization and Management Institute of Sociology, University of Lodz ul. Rewolucji 1905 41/43, 90-214 Łódź email address: beata.pawlowska@uni.lodz.pl level of power and status can shape employee relations, methods of communication and emotions in the workplace. The article answers the question of whether and how having and / or feeling a certain status and level of power implies the emergence of certain emotions. Therefore, it is important to show those activities and interactions which-as a result of a specific position in the hospital structureshape and modify the emotions of medical personnel. It should be noted here that the status and level of power is understood in accordance with Theodore Kemper's concept (1978; 1991; 2005; 2008; see also Pawłowska 2013; 2014). Medical personnel work in conditions of high emotional stress, and the emotions felt by the surveyed representatives of medical personnel determine other processes taking place in the organization, including communication and management processes. Increasing requirements, bureaucracy, lack of an appropriate motivating system, inadequate working conditions, work in conditions of uncertainty and the behavior of patients and their families significantly affect the stress experienced by a medical worker, its effectiveness and the ability to concentrate, conditioning the emer- 
gence of specific emotions. They influence interactions, often shaping their course.

This article oscillates around issues that could be described from various theoretical perspectives, and researchers of various trends and fields can see many areas of analysis. Firstly, research carried out among medical personnel on the premises of a hospital is by definition classified as research in the field of medical sociology. ${ }^{2}$ And although a lot of research has been carried out in this area, it should be noted that for the issues discussed in this article, the hospital and medical personnel are only a background. Interesting are not so much the interactions resulting from being a doctor or a nurse, but from being an employee, occupying a specific position in the organizational hierarchy, and showing the activities leading to the creation of communication methods based on managing emotions. The conducted research did not focus on the recovery process or the patient-medical staff relationship, therefore the perspective of the sociology of medicine was omitted. Secondly, the discussed research can

${ }^{2}$ It is worth mentioning at this point that research in the field of medical sociology in Poland as early as in the 1960s was conducted by Helena Csorba, who described in her monograph the social system of an internal medicine clinic (1966). Her work was continued, among others, by Magdalena Sokołows$\mathrm{ka}$, a doctor and sociologist who is called the founder of Polish medical sociology. Many authors conducting analyses in the field of medical sociology focus in their works on the issues of health and disease, as well as the socio-cultural and economic determinants of the doctor-patient relationship. I should mention here, for example, Barbara Uramowska-Żyto, Beata Tobiasz-Adamczyk, Renata Tulli, Anna Titkow, Anna Firkowska-Mankiewicz, Antonina Ostrowska and Zofia Kawczyńska-Butrym. As Justyna Klingemann (2011:217 [trans. BP]) writes: "The impact of socio-cultural factors on the health of societies is not questioned by anyone today, and the sociology of health, disease, and medicine is one of the most dynamically developing areas of sociology in Poland. This is evidenced by both the growing group of medical sociologists and the growing number of publications and academic textbooks on health issues in recent years (Barański and Piątkowski 2002; Ostrowska 2009; Piątkowski and Płonka-Syroka 2008; Piątkowski and Titkow 2002; Piątkowski 2004; Tobiasz-Adamczyk 2000, 2001)." be analyzed from the perspective of the sociology of work and organization. Although this approach is much closer to the author of this article, it also does not constitute an interpretative framework. Certainly, the hospital as an organization and bureaucratic-stratification system is a very interesting subject of research and deserves a separate article. Thirdly, the subject of the article fits within the framework of human resource management, and the management of emotions itself can be included in this trend. Fourth, when describing the professional relationship between a doctor and a nurse, we can refer to gender issues. The nursing profession is highly feminized and perhaps that is why it is often analyzed in terms of gender. ${ }^{3}$ It is less important to address this fact in the following considerations. The possessed and / or perceived levels of power and status described below apply to both genders. Apart from female nurses, there are male nurses, and female doctors work next to male doctors. Therefore, for the analysis of empirical material, the fact of occupying a specific position in the structure of the examined hospital ward was more important than belonging to a specific gender. Therefore, this issue has also been omitted in this article.

Therefore, although the analysis of the collected research material would be possible from many theoretical perspectives, this article focuses on the sociology of emotions. It is the framework of the sociology of emotions, and more specifically the

\footnotetext{
${ }^{3}$ In the considerations of many authors, the profession of a nurse is combined with that of a midwife, and so both professional groups are treated jointly. Perhaps this is due to the functioning of a trade union common to both professional groups, i.e. the National Trade Union of Nurses and Midwives. In her 2014 book titled Bunt białych czepków, Julia Kubisa described the creation, activity, and commitment of both of these professional groups in the functioning of a trade union. By describing the struggle to improve working conditions and pay, she applied the feminist perspective.
} 
structural-interactive perspective used in Theodore Kemper's approach to the study of emotions which forms the basis of the following analysis.

\section{Power, status and emotions - theoretical considerations}

Generally speaking, a social organization is a group of people who work together in an orderly and coordinated manner to achieve a certain set of goals (see Griffin 1996:34 et seq.; Nogalski, Śniadecki 1998:51). It is people who make up an organization. Without them, it would not have come into being, developing and fulfilling its assumptions. In every organization, the mutual dependence and cooperation of all entities present in the organization is important. Changing one of the elements of this system leads to changing the others. Having a particular amount of financial and material resources, each organization carries out the assigned tasks and goals (see Leavitt 1964:55).

In this article, organization is understood as an organized system of action and interaction (see Bernard 1938), the operation of which is continuous and processual (see Konecki 2007). Each organization sets the social and professional role models for employees by creating a perfectly positive, ideally negative, and average image of staff member. This allows for the determination of the way of work, performance of individual activities, and behavior in the workplace, the implementation of which is subject to control and evaluation (cf. Januszek and Sikora 2000:38-39; see Byczkowska-Owczarek, Kubczak, and Pawłowska 2020:7-8 ).

The organization is characterized by one of the most formalized structures with a strict division of tasks and responsibilities that correspond to the goals and tasks carried out by the organization is the hospital. "Hospital life is governed by regulations and procedures-implemented by the management and implemented by both medical and non-medical personnel" (Byczkowska-Owczarek, Kubczak, and Pawłowska 2020:33 [trans. BP]). An important element of the formal organization is the system of authorities and power: one results from the management of the facility, the other - from the professional skills of doctors (Domaradzki 2018:2). In hospital departments, but also between them, there is a hierarchy and a system of government through which "basic values and beliefs about culture are revealed" (Van der Geest and Finkler 2004:1995). There is a strict organizational division, a highly hierarchical structure, and a specific system of positions and roles. On the one hand, it is defined in organizational charts (director, ward manager, ward nurse, etc.) resulting from internal arrangements and legal regulations, and on the other hand, it is based on authority (Van der Geest and Finkler 2004; Chua et al. 2020). It should be remembered that hierarchy is connected with autocratic and patriarchalism, and the issues of power and authority fit into a dominant cultural pattern, which is most often the result of a weak organizational culture, characterized by elements of professional and organizational loyalty (Sułkowski 2013:93).

The hierarchy structure overlaps with the level of power and status possessed and perceived by each employee, which implies the emergence of specific emotions. "Setting a person on a social basis determines which emotions will be expressed at a certain time and place, on what basis and for what reason, by what means of expression and by whom" (Kemper 2005:73; see also Kemper 1991). There is no doubt that emotions allow a person to adapt to environmental circumstances, some of which are social re- 
sponses (see Plutchik 1991). When describing emotions in the context of power and status, reference should be made to Theodore Kemper's concept (see Kemper 1978; 2008), where interactions and changes in the relative power and status (prestige) of individuals have an impact on arousing negative and positive emotions. Power is understood as a state in interpersonal relations in which one social actor forces another to do something that the other does not want to do. The means at the disposal of the person in power are threats, the actual use of force, the deprivation of material, symbolic goods or experiences, lying, deception, and manipulation. (Kemper 1978; 1991; 2005; Pawłowska and Chomczyński, 2012:146-147; Pawłowska 2013:69). The sign of the use of force includes negative behavioral stimuli, visible in emotional expression, such as facial grimaces, gestures (e.g. waving fists), raised voice tone. The status, on the other hand, is understood as a certain state in social relations that concerns the voluntary compliance with the interests and requirements of another person. The status of one actor is granted by the other through acts of recognizing the value of the former. The manifestation of recognition of status is showing care, sympathy, support, reward, respect, friendship, and, finally, love (Kemper 2005; Pawłowska 2013:69).

And although status and power are terms more often associated with the structural paradigm, by giving them an interactive character and analyzing them in the processual context, they fit into the description made in the interpretative paradigm. It is social actors who, when interpreting the rise or fall in their own or others' status and/or level of power, give them meanings and contexts. The mutual relations of the actors lead to changes in the expression of each of them as well as to changes in the actions taken (Kemper 2008:128; cf. Kemper 1978; 2005; see
Pawłowska 2013:69-71; 2014:39-52; Byczkowska-Owczarek, Kubczak, and Pawłowska, 2020:127). From the perspective of each actor, as Kemper writes, any interactive episode within a social relationship can lead to an increase, decrease, or no change in a person's power and status in relation to another individual, or to an increase, decrease, or no change in the power and status of another person in relation to another individual. relationship to a given individual. Emotions will always arise and will depend on a specific level of power and status, taking into account the determination of who is responsible for the possible result-ourselves, the interaction partner, or a third party (cf. Kemper 2005).

Any changes in social relations can be understood as mutual changes in the power and status of actors towards each other. The mutual relations of the actors lead to changes in the expression of each of them and to changes in the structure of the relationship by marking the action on an individual, level of power and status. Thus, Kemper postulates that if we want to understand the presence of many human emotions, we must examine the structure and process of power and status in relations between social actors. This approach includes both negative emotionssuch as anger, depression, guilt, shame, anxiety-and positive emotions, such as happiness, sympathy, care, pride, and love. (Pawłowska 2013:69-70 [trans. BP]; see Kemper 2008:128; see Pawłowska and Chomczyński 2012:147)

Leaving aside the considerations about the nature of emotions, in accordance with the adopted interpretative paradigm, emotions have been defined as regulatory processes that allow for adapting and influencing the course of the communication process, establishing, maintaining, changing, or breaking the relationship between an individual 
and the environment that is triggered in a situation when a person comes into contact with external or internal stimuli that are significant for their organism or personality (Pawłowska 2013:8). At the same time, it should be remembered that emotions can be processes not only influencing the course of interaction, but also affecting the individual themselves, their behavior, gestures, perceptions, as well as their way of thinking and the reception of the outside world. They are culturally shaped and modified in accordance with the norms and values adopted in a given culture. Thus, emotions are perceived as being a central element of human experience, having an impact on the functioning of the social world and its internal order. They constitute a group bond and can shape its structure. Emotions are subject to social control and social structuring. They are associated with the performance of social roles (Pawłowska 2013:8; cf. Byczkowska-Owczarek, Kubczak, and Pawłowska 2020:117; see Binder, Palska, and Pawlik 2009:9-10). They are also a motivating force, because "they not only organize people's subjective experiences, but also energize their reactions and give them direction" (Turner and Stets 2009:25 [trans. BP]).

\section{Research methodology}

The analyses presented below are the result of research conducted by the author ${ }^{4}$ in a clinical hospital in a large provincial city, in three departments (wards) indicated by the hospital management: neu-

\footnotetext{
${ }^{4}$ The research was conducted by the author of this article together with two colleagues from the Institute of Sociology of the University of Lodz: Dominika Byczkowska-Owczarek and Anna Kubczak. Although the research was conducted jointly, separate areas of analysis were distinguished in line with the individual interests of each of the researchers. A book was prepared as a research report, which is also the basis of this article: (Byczkowska-Owczarek, Kubczak, and Pawłowska 2020).
}

rosurgery, laryngology, and intensive care. ${ }^{5}$ The research was field and exploratory research based on two methodological approaches, namely ethnography and the methodology of grounded theory, using the symbolic interactionism paradigm.

Ethnography, including the ethnography of organizations (see Kostera 2003; 2011; 2012), is a research strategy that enables the study of social aspects of the life of various communities and phenomena (see Konecki 2012:77) in their real context (see Becker and Geer 1960; Atkinson and Hammersley 1994). Entering the studied world allows for a description of the organization in question along with the presentation of the interactive processes, mutual relations, and contexts that constitute it (see Prus 1997:192). The ethnography of the organization allows us to understand the perspective of the participants of the organization (cf. Kostera 2003:12; 2011:9) and to study little-known phenomena or atypical areas of better-known phenomena (Kostera 2012:73). The aim of ethnographic research (Hammersley and Atkinson 2007) is to reconstruct and explain how and why a given process or phenomenon occurs (see Silverman 2008). The analysis of several cases (three hospital wards) simultaneously, i.e. within one research project (cf. Huberman and Miles 1984) and included in a multiple case study (see Stake 1994), allowed to examine the group of medical workers, including the determinants of relations between employees and their emotions (Byczkowska-Owczarek, Kubczak, and Pawłowska 2020:18).

The main technique for collecting data in ethnography is observation (Silverman 2001:46; see also Stake 2010). The study described here used overt,

\footnotetext{
${ }^{5}$ The names of the departments (wards) are abbreviations of full names distinguished in the organizational structure of the hospital and will be used as such in this study.
} 
multi-person, and multiple observation. The researchers participated in the functioning of the departments as a non-interfering and non-valuing observers, twice or three times a week for several hours a day during the several months of the study.

The observation is related to the naturalistic approach, which is based on the assumption that, "whenever possible, the social world should be studied in its 'natural' state, not disturbed by the researcher" (Hammersley and Atkinson 2000:16 [trans. BP]). For researchers, conducting research in the "natural environment" increases the probability of understanding the studied reality by reflecting all the elements that make up it (see Adler and Adler 1994; Fatyga 1999; Wojciechowska 2020). Robert Prus and Scott Grills emphasize that "the role of the observer, especially the participant's [author's note], allows the researcher to get closer to the life experiences of the participants to a greater extent than ordinary observation" (Prus, Grills 2003:24; see also Flick 2002; Merriam 2009).

In addition, unstructured and conversation interviews were used in the study. The data was supplemented with the already existing materials (regulations, announcements placed in the corridors and/ or rooms of medical staff, materials indicated by the medical staff and/or the hospital management). The interviews (Konecki 2000:169; Kvale 2004:17, 38, 47) were conducted with medical personnel at the managerial level, respecting the confidentiality rules. The interlocutors included: representatives of the hospital management, ward managers, and main ward nurses. All persons, except for the manager of one of the departments, agreed to the interviews being recorded. The interviews were conducted in offices or official rooms of the interviewees. They lasted from one hour to one and a half hour. The interview technique enables direct contact with the interlocutor and creates an appropriate atmosphere that is conducive to obtaining full, in-depth answers (see Byczkowska-Owczarek, Kubczak, Pawłowska 2020:19-20). A very important element of research carried out in hospital wards included informal conversations with the employees of the departments. Conversational interviews (research interview, unstructured, see Konecki 2000; Kleinknecht 2007; Given 2008) were conducted during visits to hospital wards with representatives of medical and non-medical personnel who did not perform managerial functions, such as doctors, psychologists, nurses, auxiliary nurses (matron, cleaner), administrative staff.

The coding procedures used in the data analysis derived from the methodology of grounded theory. Thus, the following were used: open/factual, selective, and theoretical coding, the preparation of memos, theoretical sampling, matrix of conditions, and focused category coding). The theoretical sampling was much more difficult due to the limited availability of some staff representatives (reluctance to participate in the study or absence from work due to the schedule or, for example, participation in training), the time-limited possibility of returning to the study site, etc. An important tool used in the research conducted within the grounded theory methodology includes sensitizing concepts. As a result of their application, the researcher can develop concepts about the studied phenomena and processes that he/she finds in the data (Charmaz 2006:17). In the case of the discussed research, such terms were "safety strategies," "types of emotional behavior," or "intragroup jokes." One type of a sensitization concept is, according to Anselm Strauss and Juliet Corbin (1990:69), in vivo codes. They make it possible to maintain the meanings at- 
tached by the participants of the research to their actions or phenomena taking place in the studied area (see Charmaz 2006:55). The in vivo codes in this study included book making, a trusting patient, individual anatomy, errand girls, and hand punching. One central category was not distinguished in the research. The category discussed in this article is status and power, which is related to the second category relevant to research, i.e. emotions. The categories distinguished during the analysis, and discussed below, are also "holding emotions," "playing disrespect" or "being infected with disrespect." Data analysis, including testing the hypotheses emerging during the study, was carried out, among others, on the basis of comparing different groups at a similar time point and making sure that the answers to the interview questions and narratives coincided with the data from the observation (see Becker and Geer 1960; Silverman 2007; 2008), i.e. with what the respondents said and how they behaved in "natural" situations, e.g. during conversations in the doctor's/nursing room, an exchange of information in hospital corridors, or during more or less formal meetings (e.g. during briefings or celebrations). ${ }^{6}$

\section{Brief characteristics of the studied hospital wards - introduction to the empirical analysis ${ }^{7}$}

The study was conducted in three departments (wards) indicated by the hospital management. Each of the departments had a different specificity and was managed in a different way.

\footnotetext{
${ }^{6}$ More information on the course of the study and subsequent analyses can be found in the already mentioned authors' book (Byczkowska-Owczarek, Kubczak, and Pawłowska 2020).

${ }^{7}$ The characteristics are also taken from the said book.
}

The heads/managers ${ }^{8}$ of the intensive care and neurosurgery departments are men, while the head of the laryngology department is a woman. Women perform the functions of ward nurses in all surveyed wards. The seniority of management staff varies, but not less than 15 years. Most of the surveyed people have higher education. The group of doctors includes people with academic degrees (titles) and specializations, some of them pursuing academic careers at the same time. All ordinators have the academic title of professor or the academic title of habilitated doctor and professor of the medical university. All ward nurses have a graduate degree, and the head of the laryngology ward has additionally completed postgraduate studies. The group of attendants (auxiliary nurses, matrons, cleaners) included people with vocational or secondary technical education. The average age of nurses is higher than the average age of doctors. The youngest employees are employed in the intensive care unit (especially nursing personnel). Only men work as operators (neurosurgeons performing operations) in the neurosurgery department. The only doctor employed in this department deals with highly specialized brain diagnostics. In the remaining surveyed departments, the medical personnel consists more or less equally of men and women. The nursing staff is mostly female. Most male nurses are employed in the intensive care ward. In the opinion of the interviewees and the hospital management, all surveyed departments are prestigious workplaces, and pride in belonging to a specific profession and a given work groupwhich is important for later analyses-was most

\footnotetext{
${ }^{8}$ In the course of the research, the nomenclature applied to the group of managerial positions changed. The name of the head of the department was changed to the manager of the department. Similar changes affected the positions of the deputies. In this article, both names will be used alternately.
} 
often emphasized by doctors from the neurosurgery department and nurses from the intensive care unit.

The wards also differ in "openness." The intensive care unit is a closed unit. Entry into the ward is in principle impossible for outsiders, and the dominant type of patient is an unconscious, lying patient. Unlike the intensive care unit, neurosurgical and laryngology units are open-ended, which means that any outsider can enter them without having to undergo sanitary procedures. In the neurosurgical and laryngology wards there are conscious and walking patients, conscious but not walking patients, as well as unconscious patients. The dominant type of patient in the laryngology department is the conscious walking patient, and in the neurosurgery ward, the patient is conscious, but with limited mobility. The state of health and the type of patient (walking-non-walking; conscious-unconscious; independent-dependent) both imply the type of therapeutic and caring activities performed by the medical staff of individual departments, as well as the type of emotions they experience.

The intensive care unit is characterized by the greatest amount of highly-specialized medical equipment (ventilators, infusion pumps, heart-lung machine, etc.) Work in this ward requires a high level of mental resilience, because due to the condition of patients, it causes the greatest emotional burden, related to, among other things, the need to provide the family with information about the patient's very serious condition, the willingness to collect organs for transplantation, or about a patient's death. Doctors (mainly anaesthesiologists) and nurses (mainly anaesthesiology nurses) from this department work simultaneously in the operating theater and in treatment rooms throughout the hospital, assisting with procedures. Doctors of all departments also work in the hospital clinic.

Two centers of power can be noticed in all the surveyed wards. One power center is traditionally the position of the head of the ward (head of the ward), the other is concentrated in the hands of the ward nurse. It is easy to notice that the centers of power are related to their position in the hierarchy of a medical facility and are consistent with the organizational assignment resulting from the organizational structure of the hospital.

\section{Status and power in the context of interactive activities}

The head of the department is the highest in the hierarchy of a hospital ward. The head's high, dominant position is emphasized not only by the academic title or having their own office, but, above all, by their decision-making and the ability to manage the work of others. Hierarchy visible in the work process of medical personnel clearly implies the emergence of specific emotions. Doctors with the highest status and prestige more often feel pride and satisfaction, and in a threatening situation, when the level of their own status decreases, anger, frustration and anger may appear, which is most often channeled vertically downward in the hierarchy, i.e. toward nurses and other medical personnel. ${ }^{9}$ Nurses communicate their negative emotions resulting from the decline in their status to the attendants (auxiliary nurses, matrons,

\footnotetext{
${ }^{9}$ It should be noted that the described activities take place between persons performing a specific profession, which implies a specific position in the hospital hierarchy. Doctors are both men and women, and the profession of nursing is also practiced by men, an example of which is the intensive care unit. Thus, the analyzed interactive game refers to people-medical employees - and is not assigned to a specific gender. When writing about doctors or heads/managers, I refer to both men and women.
} 
cleaners). Having the lowest status in the hierarchical structure of a hospital ward, they are most exposed to the accumulation of negative emotions. ${ }^{10}$

Observing the work in the surveyed hospital wards (especially in the laryngology and neurosurgery wards), it was easy to notice that nurses showed their higher level of power and status in relation to the hospital attendants (auxiliary nurses, matrons, cleaners). In the neurosurgery department, the nurses (all women) refused to eat lunch in front of, e.g., the attendants. In the common break room, auxiliary nurse (matron, cleaner) who were in the room, eating at the table, would get up and finish eating when the nurses were getting ready to eat lunch (see Byczkowska-Owczarek, Kubczak, and Pawłowska 2020:127-128). The following quotation indicates the differences in the level of status between a nurse and a nurse in charge:

Younger colleagues are so more unfriendly toward the auxiliary nurses, matrons, cleaners. I do not know if this is because the ladies are graduated from college, and the ladies in the classroom are only after the vocational school. Some of them, contrary to what their friends think, are technically trained, so they are also educated women, and they are not stupid. Well, but it happened somehow. [...] For example, today's situation from the night, the screaming of a young nurse at the orderly matron, issuing orders in an imperative manner, tolerating no objection. Commanding. [...] It is difficult, because even when I react, on the one hand I am kicked by the nurses, and on the other hand by the auxiliary nurses, matrons, cleaners. [ward nurse $]^{11}$

${ }_{10}$ The profession of attendants (auxiliary nurses, matrons, cleaners) in the surveyed departments was performed by women.

${ }^{11}$ All the quotations were translated into English for the purposes of this article.
The above quotation, apart from showing the relationship between the possessed and perceived level of power and the status, shows the status negotiation and the suspension between statuses by the ward nurse. On the one hand, she (usually a woman) belongs to the professional group of nurses and this status is close to her, on the other hand, we are dealing with a specific position in the hospital hierarchy, which is assigned a specific status of a manager and supervisor of hospital attendants (auxiliary nurses, matrons, cleaners). The ward nurse negotiates her status with herself and adjusts her actions to the current situation. Most often, she does not take any action to protect her from negative emotions.

In a conflict situation between a doctor and a nurse, the nurse, like the attendant (auxiliary nurse, matron, cleaner) in the previous example, will certainly feel a decline in power and status. The observed behavior could be stagnating, withdrawing from activities, refraining from comments, and not entering into a discussion with the doctor. Taking actions by doctors - which results in lowering the status and scope of authority of nurses in an open and public manner - creates for them the risk of disrespect on the part of the attendants (auxiliary nurses, matrons, cleaners). The room attendants (auxiliary nurses, matrons, cleaners) witnessing the situation of the nurses being humiliated may themselves stop accepting the previously agreed status and authority of the nurses during the interaction. Nurses may fear losing face (see Goffman 1981; 2008), which, in turn, is a strong motivator for corrective or even retaliatory action. Hence, nurses as well as paramedics more often than other groups of medical personnel mentioned unequal relations at the doctor-nurse/nurse level. The direction of communication is determined by the doctor. He (usually a male) is in the dominant position. He gives orders 
and expects specific action. Having the power, he/ she may force the nurse to do something that he/she does not want to do at the moment or which he/she should/should not do for formal and legal reasons. Such situations include, for example, the doctor's ordering only orally in the form of issuing medications to the patient without prior entry in certain documents, which is required by law. The nurse, by carrying out such an order, runs the risk of possible negative consequences, including legal ones. Nurses said that sometimes doctors forced them to exceed the scope of their duties, which became a source of disturbances in relations with doctors and prevented them from performing their assigned tasks on time (see Byczkowska-Owczarek, Kubczak, and Pawłowska 2020:128).

Hierarchy and the influence of status on interactions and emotions is also visible in the language code. Nurses address the doctors using the polite formula "Mister," "Mistress," "Miss." Even if in some cases they call the doctor by name, it does not happen in a public situation (e.g. in the corridor, next to the patient or their family):

I do not want to, that is, when we are here in the room, we can say to ourselves by name. As if I really don't like being in the corridor, and my colleagues, for example, shout to a doctor, “Bartuś!” I don't like it. Yes, I can go to name Bartuś here and say - "Bartuś, I need this and this," but when we are in the corridor, and if there are still visitors, God forbid. I call Mr. Bartuś "doctor" or "doctor Bartuś." [ward nurse]

The quote shows how powerful the socialization of status is. The doctor mentioned in the nurse's statement never forced her to communicate in this way. The nurse herself applies the principle resulting from her position in the hospital hierarchy. The status has been so strongly internalized that nowadays the behavior of female colleagues who do not respect the status relations is perceived as incorrect and even reprehensible. This rule is not always followed by doctors who sometimes call nurses by name, even in public situations. Relationships with people higher in the hospital hierarchy are, therefore, one of the main sources of emotions in the work of medical personnel. In the opinion of some nurses, doctors abuse their position by treating nurses as "errand girls" (in vivo code) and underestimate the value of their work. Despite having higher education and medical knowledge-often as important in everyday practice as the doctor's knowledge-nurses are treated objectively, with a clearly perceived lower level of status. As the nurse working in the neurosurgery ward stated:

[C]ooperation with doctors is usually good, but the doctor is always you! doctor! It is best if we fulfill for some of their duties, which they are aware of, and they know that they belong to them, and they try to pass them on to us, that is, they are great, they are smiling and happy. Sometimes they treat us literally as errand girls and those who rebel... I think they don't have high ratings. And there are quite a lot of such in this team, because we know our value [...]. Cooperation with some doctors with whom we work safely is efficient and runs smoothly. Some doctors, those who feel insecure, create a nervous atmosphere, they are disturbed by everything, then a person feels nervous and restless. We often feel that they do not appreciate our work, which causes unnecessary nervousness and negative emotions, such as anger, frustration. [neurosurgery, nurse]

The observations show that it happens that an experienced nurse assisting/participating in the procedure takes over the emotions of the operating 
doctor. Both the doctor and the nurse know very well that the operating physician is responsible for the life of the operated or intubated patient. In the event of unexpected difficulties, the doctor, especially the less experienced one, may panic and break down. Therefore, the nurse sometimes adjusts her actions, taking some of the responsibility, but also of the doctor's negative emotions. For example, it does not inform about the drop in blood pressure in the patient, so as not to distract the doctor who performs the brain surgery, but takes the action of equalizing the pressure on its own. Sometimes it is the nurse who tells the doctor what activities he should take or how to solve a given situation, for example regarding the course of a difficult conversation with the patient or the patient's family. However, they always do it in such a way that the doctor does not feel the risk of a drop in his/her level of status. Often doctors do not notice the help of nurses who perform emotional work for the doctor. This phenomenon can be called "holding" the emotions of the doctor by the nurses. ${ }^{12}$

\footnotetext{
${ }^{12}$ A similar phenomenon was observed by Jennifer Pierce when she conducted research in 1995 in two legal offices (a private law firm and the legal department of company $X)$. She distinguished several types of lawyers due to the use of certain emotional strategies by them. And so, "lawyers-Rambo" are people (mostly men) who demonstrate strategic thinking. They play a double emotional game. On the one hand, they are forced to show sympathy to their client, courtesy to the judge and jurors, sometimes also to witnesses, and on the other hand, signs of aggression and a show of strength in the courtroom. The second distinguished group included "mother assistants." They are caring, which means: giving support to lawyers, clients, witnesses; being nice; showing gratitude to other people (work performed on behalf of the lawyer-boss); acting as an intermediary and translator in communicating the lawyer's feelings to other people (e.g. attorney has a bad day). Peace, self-control, thoughtfulness, and comfort are all expected of them. They are often treated as invisible. They are ignored and sometimes treated as a litigation opponent. "Pierce has shown that the scope of emotional work is different for men and women-in many ways these differences reproduce gender relations across society" (Turner and Stets 2009:61-62).
}

Asymmetric doctor-nurse relations may be accompanied by negative emotions such as anger, frustration, anger, dissatisfaction, but also a feeling of low value, which may have a real impact on the manner and quality of professional duties. The research conducted by Jolanta Glińska and Magdalena Lewandowska confirms that the factor that disrupts proper cooperation in the hospital ward is stress experienced by the nurse, the main reason of which is the doctors (Glińska and Lewandowska 2007:249). As I wrote in the book quoted before (Byczkowska-Owczarek, Kubczak, and Pawłowska 2020), in the opinion of the surveyed nurses, "a doctor is always a doctor, and we are only nurses." Despite the satisfactory working atmosphere in hospital wards, positive relations, jokes and trust between medical staff, doctors often make nurses feel that they are better than them as a professional group, sometimes diminishing the value of the nursing staff. Such behaviors most often appear in crisis, stressful and difficult situations for the doctor and/or the ward. In the research conducted by Halina Zielińska-Więczkowska and Anna Buśka (2010:7), the same opinion regarding the nurse-doctor relationship is presented by more than half of the nurses. Kazimiera Zdziebło and Ewa Kozłowska (2010:218) write that health care workers, including nurses, are in the professional group that is most exposed to mobbing, because doctors often create situations that cause conflicts, misunderstandings, and a negative atmosphere in cooperation.

Referring to Theodore Kemper's concept, it can be stated that people in power (doctors) have the possibility of humiliating and deprecating people who are lower in the professional hierarchy (nursing personnel). A higher status gives one the opportunity to give and receive respect, accept recognition, but also the requirement to show submission and 
obedience. It happens that the operating doctors blame the nurses for the lack of equipment, shouting in a raised voice, "How can it be?! What should I work with?!" In fact, each of the surveyed nurses was able to cite a situation in which they felt negative emotions in contact with the doctor. For some, it was demeaning and frustrating. Others described actions such as incidental. They rationalized, claiming that these are behaviors that should not be worried about; they summed them up with the saying "something bit him," "he had a bad day," "she got up with her left leg," "she is before her menstruation" (see Byczkowska-Owczarek, Kubczak, and Pawłowska 2020:129-130).

It should be noted that the inequality of statuses results mainly from its perception by the respondents themselves. It functions in the perception of both doctors and nursing staff, and had been socialized in the early stages of work or in education. The adoption of such a framework of statuses and no other can result from the schemas and stereotypes adopted by both sides of the interactive process. Most likely, it is a legacy of a past period, when most nurses did not have higher education. They usually completed nursing high school or medical college. The unequal distribution of resources (education) entitled and at the same time justified the perception of a higher status by doctors and a lower status by nursing staff. Therefore, they submitted to the doctor's authority, developing defense mechanisms that prevented them from feeling the loss of face.

Interestingly, none of the surveyed doctors, both men and women, referred to the emotional states of the nursing staff when speaking about emotions in their work. Doctors did not rationalize the behavior and emotions of staff who are lower in the hospital hierarchy than their own position. Getting used to the situation of lowering the status of a nurse can result in a lack of mutual respect in the doctor-nursing staff relationship and a lower level of trust-so needed in the work of medical personnel-and can significantly affect the level of perceived job satisfaction by nursing staff. The level of mutual trust between nurses, doctors, and doctors and nursing staff is higher when the relations between employees move from a purely professional area to a social and friendly, or even just friendly, area. As the level of mutual trust increases, the level of emotional commitment increases, too. Nursing staff from the intensive care unit more often than those from other units referred to positive relations between colleagues. Their nursing team was described as very pleasant and the atmosphere as friendly. It is in this ward that nurses maintain contacts outside of work more often than in other wards. This is also where more situations happen in which positive emotions emerge, such as joy and satisfaction.

\section{A "game of disrespect"}

An interesting phenomenon that has been observed in the surveyed hospital wards is "getting infected" with a lack of respect and the façade of kindness and smiles. As mentioned above, the top position in the hierarchy of a hospital ward is occupied by the head of the hospital ward. Their high status and prestige, in their opinion, entitle them to expect obedience and subordination of other medical personnel employed in a given ward. Employees who do not accept this state of affairs and oppose, or even rebel against such perception of them as subordinate persons, feel the power of those higher in the hierarchy more strongly. And so some doctors mentioned that they were not allowed to perform treatments considered more prestigious. Both doctors and nurses in their statements referred to the unequal allocation of pa- 
tients, division of tasks, working hours, on-call duty, and the requirements for maximum involvement in work, including scientific work. Doctors often interpreted these actions as disrespecting them and their work. This behavior implied the emergence of negative emotions that were passed down to the nurses and attendants (auxiliary nurses, matrons, cleaners). In this way, individuals at different levels of the hospital hierarchy "contract" negative emotions (cf. Collins 2004), passing them down to various groups of medical and non-medical workers. Doctors, preventing a lowering of their self-esteem and defending themselves against lowering their own status and prestige, direct similar actions toward the nursing staff, and those, in turn, do this toward the attendants (auxiliary nurses, matrons, cleaners). This process can be called a "game of disrespect." They have internalized and accepted their low status, and manage negative emotions-such as embarrassment or shame-from disrespect. The auxiliary nurses (matrons, cleaners) rationalized their actions. They believe that "someone has to do these things." They say they help patients and keep the hospital clean. They believe that the hospital would not be able to function efficiently without them. This technique of managing emotions is very effective and can protect against frustration and apathy. One of the measures to protect nurses from negative emotions is to avoid situations that cause these feelings. It can be, for example, setting up schedules and rosters in such a way as not to work with a doctor whose behavior causes negative emotions. A strategy that protects against negative emotions is also feeling proud of performing a profession whose mission is to help the sick and the suffering (see Byczkowska-Owczarek, Kubczak, and Pawłowska 2020:130). Research conducted by Agnieszka Bielemuk and her team (2007:27-33) shows that interpersonal relations between doctors and nurses are influenced by the length of service of the latter professional group. Nursing staff with a long experience of employment definitely more often describe these relations with doctors as good, as opposed to nurses with short work experience. Among nurses with a short period of work, contacts with doctors were described much more often as sufficient or even insufficient. The research described herein only partially confirms this thesis. In fact, nurses with longer experience in the neurosurgery ward describe their relations with doctors as positive and partner-like, full of mutual respect and warmth. They say that they know what to do themselves, and doctors trust them. Younger nurses find that they sometimes feel the contemptuous behavior of doctors, or indicate a disrespect or relationship difficulty. However, the situation is different with regard to the intensive care unit. In the intensive care ward, the employed nursing personnel has the shortest work experience, and the relations between the medical staff are described there as very good. There is the highest level of mutual trust and this is where nurses most often "hold" the emotions of doctors. This mainly concerns anesthesiology and ward nurses. In the laryngology ward, relationships are most often reduced to procedures and commands issued vertically downward. In each of the surveyed departments, the quality of contacts is positively influenced by conscientiousness on both sides of the relationship, but also by communicativeness, trust, openness, and understanding (cf. Byczkowska-Owczarek, Kubczak, and Pawłowska 2020:131).

\section{Pride in the context of the level of power and status}

Pride is a positive emotion that causes individuals to tune in to each other's reactions (assuming the role of the other) (see Turner and Stets 2009:174). Pride is 
a signal of the intact bond between the partners of the interaction. It is a secondary emotion built on positive emotions and is part of the "happy emotions family" (Goleman 1997). Pride in Kemper's (2005) concept is the result of satisfaction arising from the increase in our status and/or power, which, in our opinion, we deserve as a result of actions taken by ourselves or actions taken by someone else (Pawłowska 2013:198).

The emotion of pride was most clearly noticed in the doctors of the neurosurgery department. They are proud of the specialization they have chosen, believing that the neurosurgeon is a top-class specialist, knowledgeable and working in the least foreseeable area of the human body, namely the brain. Such a perception of oneself as a person "chosen" to perform the most serious procedures and thus having the highest prestige and status is socialized at an early stage of medical education and maintained from the beginning of professional work. From choosing a specialization to which the best students are admitted, to working in a department considered prestigious. As the head of the department said, "The best students become neurosurgeons." Among other things, due to the significantly difficult access to the neurosurgical specialization and the need to constantly improve qualifications, neurosurgeons value their status, considering themselves the best of the best. Pride and the perceived prestige both affect the quality of interpersonal relations and the behavior of doctors in relation to other medical staff as well as patients and their families (see Byczkowska-Owczarek, Kubczak, and Pawłowska 2020:126). It was among the neurosurgeons that one could hear the most jokes that indicated in the perception of doctors a sense of the great prestige of the profession of a male neurosurgeon and clearly pointing to the highest position in the hospital hier- archy of medical professions. An exemplary joke of this type-which intended to show the differences in the status of neurosurgeons and doctors of other specialties-was heard during the observation in the neurosurgery department: "What is the peak concentration of an orthopedist? Chewing gum and riding the elevator at the same time." Depreciating doctors of other specialties is one way of assigning oneself a higher status. It is also an expression of group unity and the emergence of a clear principle of separateness, expressed in terms of "us" and "them." While observing the situation of discussing the case of a specific patient, one of the doctors said: "Call the psychiatric ward. Maybe they will be useful for something. Let their thorough knowledge apply." In response, the team laughed.

It is also important that the employees of the department are mostly men. Women are unlikely to be admitted to the profession of neurosurgeon, and if they complete their specialization, they do not do surgery. The jokes, mainly observed in the neurosurgery department, also concern the doctor-patient relationship:

Since we are quite familiar here, how to say, relationships, when I was sitting in the doctor's room, some woman would come and say: "Is there any doctor," then XY said: "There is no doctor?" "Oh, the deputy physician is here!" [head of neurosurgery]

While joking can be one of the methods of reducing emotional tension, they certainly emphasize the neurosurgeon's status, prestige, and position in the hospital hierarchy. They definitely maintain the sense of group elitism and maintain the status $q u o$, reproducing the established social order. In this case, pride resulting from the performance of a specific profession-as well as belonging to a spe- 
cific social group, related to the status and scope of power-influences the feeling of job satisfaction. Referring to research conducted by myself in another professional group-namely teachers-I can say that the frequency of the feeling of pride translates into perceived job satisfaction and motivation to work (see Pawłowska 2020).

In the described studies, the nursing staff of the intensive care ward and the doctors of the neurosurgery ward most often spoke about the feeling of pride and prestige at work. The respondents pointed to the prestige of the profession, including specialization and work in a specific branch. The high level of job satisfaction among the nursing personnel in the intensive care ward can be a consequence of the relatively young age of the staff (average age is 27). The only nurse deviating from this average is the main ward nurse. The nature of working in an intensive care unit can also affect the way nurses feel pride. The work here is extremely responsible and emotionally difficult, and the difficulty of medical cases requires intensification of efforts, and perhaps that is why a relatively high rotation of the nursing personnel employed in this ward is noticeable here. As the interlocutors pointed out, this results in gaining vast experience in a relatively short time: "experience gained in the intensive care ward in one month is 3 years of work in another ward." The difficulty of working in the department implies the perception of their work as more important and more prestigious. This leads to an increase in their perceived status in relation to the status of people working in other departments. The increase in the "I" status that we believe we deserve leads to satisfaction (including job satisfaction) and, as a consequence, a feeling of happiness and pride. This process is most apparent among the nursing staff in the intensive care unit. They point out that "not ev- eryone can work here" and "it is very burdensome." They emphasize that they become an authority for the nursing staff of other wards when they change jobs to another ward.

\section{Summary}

By observing and analyzing the activities of medical personnel in three hospital wards, the article relates them to the level of power and status, implying the emergence of specific emotions and influencing the interaction situation. It should be emphasized that the perception of a specific level of power and status, most often resulting from the hospital hierarchy, probably does not result from gender differences and is the result of the assumed professional role. A specific professional role is assigned a particular and negotiated level of power and status. When starting their professional career, medical personnel internalize not only organizational norms and values, but also the methods of managing emotions and the emotions they experience. The respondents use a rather intuitive way of managing their own emotions and the emotions of their interactive partners. They lack knowledge of studies and scientific publications about emotional management as well as ways of dealing with traumatic and difficult experiences. It should be emphasized that there is no psychological support or psychological or social education.

The working day of a doctor or a nurse is quite unpredictable. The consequence is frustration which, if not properly managed, may have a negative impact on the work and cooperation process, including mutual trust and respect, and, in fact, their lack. Stress and frustration cause doctors to shift some of their duties and responsibilities onto nurses. All this affects the nature of the doctor-nurse relationship, where it hap- 
pens that there is a lack of respect and mutual respect for each other's rights and obligations. [Byczkowska-Owczarek, Kubczak, and Pawłowska 2020:132 [trans. BP]]

The issue that brings healthcare professionals closer together, as most clearly seen in the intensive care department, is the difficult and emotional experience of caring for patients. This type of work requires efficient cooperation and mutual trust of individual staff members in each other. Due to the specificity of work in the ward, where there are sudden situations that threaten the life of patients or result in their death-and at the same time are very emotional for both doctors and nursing staff-we observe the emergence of a higher "I" status.

In the opinion of the interviewees and the hospital management, all the surveyed departments are prestigious workplaces, while pride in belonging to a specific profession and a specific group of employees was most often emphasized by doctors from the neurosurgical ward and nurses from the intensive care ward. The emotion of pride arises as a result of actions taken by the employee, which are positively assessed by superiors and colleagues (e.g. as a result of a well-conducted procedure). In addition, it ap- pears as a result of the prestige of the profession or workplace (hospital or ward). It was especially visible among doctors -who are neurosurgeons. They emphasized many times that this specialization could only be selected and performed by the best of doctors (cf. Johannessen 2014; see Byczkowska-Owczarek, Kubczak, and Pawłowska 2020:127).

Referring to the cited concept of Kemper, it can be said that power and status together form the framework of social relations, which is at the basis of all social interactions. Pride is the result of satisfaction coming from the increase in one's status, which, in their opinion, they deserve as a result of the actions they have taken (Pawłowska 2013:180). Authority is understood as the simultaneous possession of power and high status (Pawłowska 2014:49). It should be remembered that the perception of power and status, and, consequently, the emergence of a particular relationship and emotions, will depend, inter alia, on the specificity of culture determining the individual level of power and status as well as their perception, social position (perceived differently at different times and in different communities), and, finally, on the specificity of social organizations, which can determine different patterns of emotional behavior by assigning them different statuses.

\section{References}

Adler, Patricia and Peter Adler. 1994. "Observation techniques." Pp. 377-392 in Handbook of qualitative research, edited by N. Denzin and Y. S. Lincoln. Thousand Oaks, CA: Sage.

Atkinson, Paul and Martyn Hammersley. 1994. “Ethnography and participant observation." Pp. 248-261 in Handbook of qualitative research, edited by N. Denzin and Y. S. Lincoln. Thousand Oaks, London: Sage.
Barański, Jarosław and Włodzimierz Piątkowski. 2002. Zdrowie $i$ choroba. Wybrane problemy socjologii medycyny. Wrocław: Wrocławskie Wydawnictwo Oświatowe.

Becker, Howard S. and Blanche Geer. 1960. "Participant observation: The analysis of qualitative field data." Pp. 267-289 in Human Organization Research: Field Relations and Techniques, edited by R. N. Adams and J. J. Preiss. Homewood, IL: Dorsey. 
Bernard, Chester I. 1938. The Functions of the Executive. Cambridge, MA: Harvard University Press.

Bielemuk, Agnieszka et al. 2007. “Ocena relacji interpersonalnych w grupie zawodowej pielęgniarka-lekarz." Pp. 25-34 in Problemy terapeutyczno-pielegnacyjne od poczęcia do starości, edited by E. Krajewska-Kułak et al. Bialystok: Akademia Medyczna w Białystoku.

Binder, Piotr, Hanna Palska, and Wojciech Pawlik, eds. 2009. Emocje a kultura iżycie społeczne. Warsaw: Wydawnictwo IFiS PAN.

Brief, Arthur P. and Howard M. Weiss. 2002. "Organizational Behavior. Affect in the Workplace." Annual Review of Psychology 53:279-307.

Byczkowska-Owczarek, Dominika, Anna Kubczak, and Beata Pawłowska. 2020. Za drzwiami oddziału. Badania etnograficzne w szpitalu. Lodz: Wydawnictwo Uniwersytetu Łódzkiego.

Charmaz, Kathy. 2006. Constructing Grounded Theory: A Practical Guide Through Qualitative Analysis. London, New Delhi: Sage Publications.

Chua Wei et al. 2020. "A call for better doctor-nurse collaboration: A qualitative study of the experiences of junior doctors and nurses in escalating care for deteriorating ward patients." Australian Care 33(1):54-61. DOI: 10.1016/j.aucc.2019.01.006.

Collins, Randall. 2004. Interaction ritual chains. Princeton, NJ: Princeton University Press.

Csorba, Helena. 1966. Szpital-pacjent: system społeczny kliniki internistycznej. Wroclaw: Zakład Narodowy im. Ossolińskich.

Domaradzki, Jan. 2018. Szpital jako instytucja społeczna. Retrieved March 31, 2020 (https://www.ump.edu.pl/media/uid/ f17222b7a2b-23c9792a/562330.pdf).

Fatyga, Barbara. 1999. Dzicy z naszej ulicy. Antropologia kultury młodzieżowej. Warsaw: Uniwersytet Warszawski.

Flick, Uwe. 2002. An introduction to qualitative research. London: Sage.

Given, Lisa M. 2008. The SAGE Encyclopaedia of Qualitative Research Methods, vol. 1-2. Thousand Oaks, CA: Sage Publications.

Glińska, Jolanta and Magdalena Lewandowska. 2007. “Autonomiczność zawodu pielęgniarskiego w świadomości pielęgniarek z uwzględnieniem pełnionych funkcji zawodowych." Problemy Pielegniarstwa 15(4):249-253.
Goffman, Erving. 1981. Człowiek w teatrze życia codziennego. Warsaw: PIW.

Goffman, Erving. 2008. Zachowanie w miejscach publicznych, o spotecznej organizacji zgromadzeń. Warsaw: Wydawnictwo Naukowe PWN.

Goleman, Daniel. 1997. Inteligencja emocjonalna. Poznan: Media Rodzina.

Griffin, Ricky W. 1996. Podstawy zarządzania i organizacji. Warsaw: PWN.

Hammersley, Martyn and Paul Atkinson. 2000. Metody badań terenowych. Poznan: Wydawnictwo Zysk i S-ka.

Hammersley, Martyn and Paul Atkinson. 2007 Ethnography. Principles in Practice. New York: Taylor and Francis.

Hochschild, Arlie R. 1983. The Managed Heart: Commercialization of Human Feeling. Berkeley: University of California Press.

Hochschild, Arlie R. 2009. Zarządzanie emocjami. Komercjalizacja ludzkich uczuć. Warsaw: Wydawnictwo Naukowe PWN.

Huberman, Michael A. and Matthew N. B. Miles. 1984. Innovation up Close: How School Improvement Works. New York: Plenum Press.

Januszek, Henryk and Jan Sikora. 2000. Socjologia pracy. Poznan: Wydawnictwo Akademii Ekonomicznej w Poznaniu.

Johannessen, Lars E. F. 2014. “The narrative (re)production of prestige: How neurosurgeons teach medical students to valorise diseases." Social Science \& Medicine 120:85-91.

Kemper, Theodore D. 1978. A Social Interactional Theory of Emotions. New York: Wiley.

Kemper, Theodore D. 1991. "Predicting Emotions from Social Relations." Social Psychology Quarterly 54:330-342.

Kemper, Theodore D. 2005. "Modele społeczne w wyjaśnianiu emocji [Social Models in Explaining Emotions]." Pp. 72-87 in Psychologia emocji [Psychology of Emotions], edited by M. Lewis and J. M. Haviland-Jones. Gdansk: Gdańskie Wydawnictwo Psychologiczne.

Kemper, Theodore D. 2008. "Power, Status, and Emotions." Pp. 369-383 in Emotions. A Social Science Reader, edited by M. Greco and P. Stenner. London, New York: Routledge Taylor and Francis Group. 
Kleinknecht, Steven. 2007. "An interview with Robert Prus: His Career, Contributions, and Legacy as an Interactionist Ethnographer and Social Theorist." Qualitative Sociology Review 3(2):221-288.

Klingemann, Justyna I. 2011. "Magdalena Sokołowska - inspiracje i kontynuacje (recenzja z: Włodzimierz Piątkowski (red.) Socjologia z medycyną. W kręgu myśli naukowej Magdaleny Sokołowskiej." Studia Socjologiczne 3(202):217-222.

Konecki, Krzysztof. 2000. Studia z metodologii badań jakościowych. Teoria ugruntowana. Warsaw: Wydawnictwo Naukowe PWN.

Konecki, Krzysztof. 2007. "Procesualne ujęcie organizacji. Organizacje, struktury, procesy, tożsamości." Pp. 7-22 in Zarzązanie organizacjami. Organizacja jako proces, edited by K. Konecki and P. Chomczyński. Lodz: Wydawnictwo Uniwersytetu Łódzkiego.

Konecki, Krzysztof. 2012. “Etnografia socjologiczna." Pp. 7782 in Słownik socjologii jakościowej, edited by K. Konecki and P. Chomczyński. Warsaw: Difin.

Kostera, Monika. 2003. Antropologia organizacji. Metodologia badań terenowych. Warsaw: Wydawnictwo Naukowe PWN.

Kostera, Monika, ed. 2011. Etnografia organizacji. Badania polskich firm i instytucji. Sopot: Gdańskie Wydawnictwo Psychologiczne.

Kostera, Monika. 2012. "Etnografia organizacji." Pp. 73-77 in Stownik socjologii jakościowej, edited by K. Konecki and P. Chomczyński. Warsaw: Difin.

Kubisa, Julia. 2014. Bunt białych czepków. Analiza działalności zwiazkowej pielegniarek i położnych. Warsaw: Wydawnictwo naukowe SCHOLAR.

Kvale, Steinar. 2004. InterViews. Wprowadzenie do jakościowego wywiadu badawczego. Bialystok: Trans Humana.

Leavitt, Harold J. 1964. "Applied organization change in industry structural, technical, and human approaches." Pp. 55-71 in New Perspectives in Organization Research, edited by W. Cooper, H. Leavitt, and M. Shelly. New York, London, Sydney: John Wiley \& Sons Inc.

Merriam, Sharon. 2009. Qualitative research. San Francisco: Jossey-Bass.

Nogalski Bogdan and Janusz Śniadecki. 1998. Kształtowanie umiejętności menedżerskich. Bydgoszcz: Oficyna Wydawnicza Ośrodka Postępu Organizacyjnego Sp. z o. o.
Ostrowska, Antonina. 2009. Socjologia medycyny. Podejmowane problemy, kategorie analizy. Warszawa: Wydawnictwo IFiS PAN.

Pawłowska, Beata. 2013. Emocje społeczne w pracy nauczyciela i przedstawiciela handlowego [Social Emotions in the Work of Teachers and Salesmen]. Lodz: Wydawnictwo Uniwersytetu Łódzkiego.

Pawłowska, Beata. 2014. “Emocje społeczne w teorii Theodore’a Kempera [Social Emotions in Theodore Kemper's Theory]." Pp. 39-52 in Emocje w życiu codziennym [Emotions in Everyday Life], edited by K. Konecki and B. Pawłowska. Lodz: Wydawnictwo Uniwersytetu Łódzkiego.

Pawłowska, Beata. 2020. "Pride in Teachers' Everyday Work. Conditions and Contexts." Qualitative Sociology Review 16(1):2848. DOI: https://doi.org/10.18778/1733-8077.16.1.03.

Pawłowska, Beata and Piotr Chomczyński. 2012. "Sposoby radzenia sobie z emocjami negatywnymi na przykładzie grupy nauczycieli." Studia Edukacyjne 21:141-162.

Piątkowski, Włodzimierz. 2004. Zdrowie, choroba, społeczeństwo: studia z socjologii medycyny. Lublin: Wydawnictwo UMCS.

Piątkowski, Włodzimierz and Bożena Płonka-Syroka. 2008. Socjologia i antropologia medycyny $w$ działaniu. Wrocław: Aboretum.

Piątkowski, Włodzimierz and Anna Titkow. 2002. W stronę socjologii zdrowia. Lublin: Wydawnictwo UMCS.

Pierce, Jennifer L. 1995. Gender trials: Emotional lives in contemporary law firms. Berkeley: University of California Press.

Plutchik, Robert. 1991. “Emotions and Evolution." Pp. 37-58 in International Review of Studies on Emotion, edited by K. T. Strongman. Chichester: Wiley.

Prus, Robert. 1997. Subcultural Mosaics and Intersubjective Realities. An Ethnographic Research Agenda for Pragmatizing the Social Sciences. New York: State University of New York Press.

Prus, Robert and Scott Grills. 2003. The Deviant Mystique: Involvements, Realities and Regulation. Westport: Praeger Publishers.

Rafaeli, Anat and Robert I. Sutton. 1987. “Expression of emotion as part of the work role." The Academy of Management Review 12(1):23-37.

Silverman, David. 2001. Interpreting Qualitative Data. Methods for analyzing talk, text and interaction. London, Thousand Oaks, New Delhi: Sage Publication. 
Silverman, David. 2007. Interpretacja danych jakościowych [Interpreting Qualitative Data]. Warsaw: Wydawnictwo Naukowe PWN.

Silverman, David. 2008. Prowadzenie badań jakościowych. Warsaw: Wydawnictwo Naukowe PWN.

Stake, Robert E. 1994. "Case Studies." Pp. 236-247 in Handbook of Qualitative Research, edited by N. Denzin and Y. S. Lincoln. Thousand Oaks, London: Sage.

Stake, Robert E. 2010. Qualitative Research. Studying how things work. New York, London: The Guilford Press.

Strauss Anselm and Juliet Corbin. 1990. Basics of Qualitative Research: Grounded Theory Procedures and Techniques. Newbury Park-London-New Delhi: Sage Publications.Sułkowski, Łukasz. 2013. "Zmiana kulturowa w polskich szpitalach - wyniki badań." Przedsiębiorczość i Zarządzanie XIV(10):83-96.

Tobiasz-Adamczyk, Beata. 2000. Wybrane elementy socjologii zdrowia i choroby. Kraków: Wydawnictwo UJ.
Tobiasz-Adamczyk, Beata. 2001. Relacje lekarz-pacjent w perspektywie socjologii medycyny. Kraków: Wydawnictwo UJ.

Turner, Jonathan H. and Jan E. Stets. 2009. Socjologia emocji [Sociology of Emotions]. Warsaw: Wydawnictwo Naukowe PWN.

Van der Geest, Sjaak and Kaja Finkler. 2004. "Hospital ethnography: introduction." Social Science \& Medicine 59(2004):1995-2001.

Wojciechowska, Magdalena. 2020. Dwie matki jednego dziecka. Macierzyństwo nieheteronormatywne w doświadczeniu kobiet wychowujacych dzieci poczęte w zwiazku jednoptciowym. Lodz: Wydawnictwo Uniwersytetu Łódzkiego.

Zdziebło, Kazimiera and Ewa Kozłowska. 2010. “Mobbing w środowisku pracy pielęgniarek." Problemy Pielęgniarstwa 18(2):212-219.

Zielińska-Więczkowska, Halina and Anna Buśka. 2010. “Satysfakcja zawodowa pielęgniarek na tle wybranych czynników środowiska pracy." Pielegniarstwo XXI wieku 3-4:32-33.

\section{Citation}

Pawłowska, Beata. 2021. “Emotions of Medical Personnel versus the Status and Power at Work in Hospital Wards.” Przeglad Socjologii Jakościowej 17(4):68-87. Retrieved Month, Year (www.przegladsocjologiijakosciowej.org). DOI: https://doi.org/10.18778/1733-8069.17.4.04

\section{Emocje personelu medycznego a status i władza w pracy w szpitalu}

Abstrakt: Szpital charakteryzuje się jedną z najbardziej sformalizowanych struktur ze ścisłym podziałem zadań i obowiązków. Istotnym elementem każdej organizacji formalnej jest system autorytetów i władzy. Pomiędzy oddziałami szpitalnymi oraz w obrębie każdego z nich zaznacza się hierarchia oraz system władzy. Na ten układ hierarchii nakłada się odczuwalny i percypowany przez każdego pracownika poziom władzy i statusu, który implikuje pojawienie się określonych emocji. Wpływają one na interakcje, formując ich przebieg. Opisując emocje w kontekście władzy i statusu, w artykule będę się odnosić do koncepcji Theodore’a Kempera, gdzie interakcje i zmiany względnej władzy i statusu (prestiżu) jednostek mają wpływ na wzbudzanie negatywnych i pozytywnych emocji. Celem artykułu jest ukazanie, jak indywidualnie oznaczony poziom władzy i statusu może kształtować relacje pracownicze, sposoby komunikowania oraz emocje w miejscu pracy. Artykuł odpowiada na pytanie, czy i jak posiadanie i/lub odczuwanie określonego statusu i poziomu władzy implikuje pojawienie się określonych emocji. Zatem istotne jest ukazanie tych działań i interakcji, które wynikając z zajmowanej w strukturze szpitalnej określonej pozycji - kształtują i modyfikują emocje personelu medycznego.

Całość rozważań oparta jest na etnograficznych badaniach jakościowych prowadzonych w trzech oddziałach szpitalnych różniących się co do charakteru pracy w oddziale oraz typem leczonych pacjentów. W artykule opisano trzy z wyróżnionych kategorii, to jest "grę w brak szacunku”, „trzymanie emocji” oraz „dumę". W toku analiz stwierdzono, że hierarchiczność i określony poziom władzy implikuje pojawienie się emocji dumy, satysfakcji, zadowolenia i prowadzi do zwiększenia poziomu zaufania pomiędzy personelem medycznym. Duma wynika z przynależności do określonego zawodu i określonej grupy pracowniczej, pojawia się jako rezultat dobrze przeprowadzonego zabiegu, albo wykonania czynności trudnej, której opanowanie wymagało czasu. Duma pojawia się także jako wynik prestiżu zawodu lub miejsca pracy (szpitala, oddziału).

Słowa kluczowe: emocje, praca, duma, status, władza, Theodore Kemper, personel medyczny, szpital 